\title{
Organized Exchanges and the Regulation of Dual Class Common Stock
}

\author{
Daniel R. Fischel $\dagger$
}

Entrepreneurs of firms who decide to raise funds from capital markets have considerable discretion in choosing an appropriate capital structure. They must decide, for example, whether to sell common or preferred stock, issue secured or unsecured debt, or undertake some combination of the above." They also must decide what the voting rights of the various classes of investors will be.

One important decision that must be made is under what circumstances, if any, classes of investors other than common stockholders will have the right to vote. Another important decision is what the voting rules will be for common stockholders. Some of the possibilities include one share-one vote, cumulative voting, or multiple classes of common stock with unequal voting rights. Multiple classes of common stock with unequal voting rights are commonly referred to as dual class common stock.

Whatever voting rules are selected, it is possible to alter the rules in the future in light of changed circumstances. Thus cumulative or dual class voting might be eliminated or implemented, notwithstanding the prior rule, if certain previously agreed upon procedures are followed (typically approval of the proposed change by shareholders).

The laws of many states-including Delaware, the state in

$\dagger$ Professor of Law, The University of Chicago. I would like to thank Alan Frankel and David Ross for their invaluable assistance and Geoffrey Miller, Richard Posner, and Alan Sykes for helpful comments. Another version of this paper will appear in John C. Coffee, Louis Lowenstein, and Susan Rose-Ackerman, eds., Knights, Raiders \& Targets: The Impact of the Hostile Tender Offer (forthcoming 1987).

1 There is an enormous body of literature, both theoretical and empirical, concerning the relationship between capital structure and firm value. The seminal paper is Franco Modigliani and Merton H. Miller, The Cost of Capital, Corporation Finance, and the Theory of Investment, 48 Am. Econ. Rev. 261 (1958). See also David Cass and Joseph E. Stiglitz, The Structure of Investor Preferences and Asset Returns, and Separability in Portfolio Allocation: A Contribution to the Pure Theory of Mutual Funds, 2 J. Econ. Theory 122 (1970); Fischer Black and Myron Scholes, The Effects of Dividend Yield and Dividend Policy on Common Stock Prices and Returns, 1 J. Fin. Econ. 1 (1974); Joseph E. Stiglitz, On the Irrelevance of Corporate Financial Policy, 64 Am. Econ. Rev. 851 (1974); Eugene F. Fama, The Effects of a Firm's Investment and Financing Decisions on the Welfare of its Security Holders, 68 Am. Econ. Rev. 272 (1978). 
which most firms incorporate-impose only the most minimal regulation on the choice of voting rules. ${ }^{2}$ Dual class voting, like cumulative voting and virtually all other possible voting schemes, is neither prohibited nor required. ${ }^{3}$ The voting rules are considered to be a matter of private contract between the firm and its various types of investors.

The organized exchanges have taken several approaches toward dual class voting. The National Association of Securities Dealers (NASD) has placed no restrictions on the trading of dual classes of common stock on its automated quotation system (NASDAQ). The American Stock Exchange (AMEX) allows the trading of dual classes of common stock, provided that the inferior voting stock has some voting rights." Historically, the New York Stock Exchange (NYSE) is at the opposite extreme from the NASD. Since 1926, the NYSE has prohibited listed firms from issuing any type of dual class common stock. ${ }^{5}$

In recent years, however, there has been considerable debate among member firms on the NYSE whether to retain the prohibition against dual class common stock. In January, 1985, an advisory committee recommended to the Board of Directors of the NYSE that the exchange allow the trading of dual class common stock in certain situations. ${ }^{8}$ Although the NYSE decided in June, 1986 to accept the advisory committee's recommendation, ${ }^{7}$ the change will not be effective until approved by the Securities and Exchange Commission.

The current controversy concerning dual class common stock also has attracted the attention of Congress. Legislation has been introduced in both houses of Congress that would require the NASD and the AMEX to adopt the historic NYSE prohibition on the trading of dual class common stock. The stated justification for the proposed legislation is that the ability of exchanges to choose different rules regarding the trading of dual class common stock will lead all exchanges to adopt the rule that is most detrimental to

See, e.g., 8 Del. Code $\S \S 151($ a), 221 (firms permitted to give shares any number of votes and to give votes to bondholders in addition to, or instead of, shareholders); $8 \mathrm{Del}$. Code $\S 214$ (cumulative voting optional).

s See generally Annot., Validity of Variations from One Share-One Vote Rule Under Modern Corporate Law, 3 ALR 4th 1204 (1981).

- See American Stock Exchange Company Guide § 122.

- See NYSE Listed Company Manual § 313.

- See NYSE Dual Class Capitalization: Initial Report of the Subcommittee on Shareholder Participation and Qualitative Listing Standards (Jan. 3, 1985).

7 See Big Board Agrees to Let Companies List More Than One Class of Common Stock, Wall St. J. 2, col. 3 (July 7, 1986). 
investors. By preventing this "race to the bottom" among exchanges and forcing all exchanges to adopt the NYSE's prohibition on trading of dual class common stock, the argument runs, the proposed legislation will protect investors.

The NYSE itself has endorsed this "race to the bottom" argument in explaining the departure from its historic prohibition on the listing of dual class common stock. The NYSE has stated that it would prefer to retain the prohibition, but only if other exchanges adopted the prohibition or were forced to do so by federal regulation. ${ }^{8}$

This article analyzes whether exchange rules permitting the trading of dual class common stock are economically beneficial to investors and whether federal regulation is necessary to protect investors from such exchange rules. Part I discusses the role of exchanges and the incentives of exchanges to offer the type of transaction and ancillary services that investors want. The "race to the bottom" thesis is critically analyzed in part II. Part III discusses the reasons why some firms might choose to have dual class common stock in light of the economic theory of voting; it also summarizes the available empirical evidence. Part IV analyzes the relationship between dual class common stock and the current debate concerning defensive tactics in response to takeovers. Part V discusses the effects of a change in the NYSE's historic prohibition on the listing of dual class common stock. Part VI is a conclusion.

\section{Voting Rules and the Role of Organized Stock Exchanges}

\section{A. The Economic Function of Exchanges}

Stock exchanges facilitate transactions between buyers and sellers of securities. They do this by providing a centralized location, such as an exchange floor, for trades to take place or by providing an electronic system to perform the same function. As with all marketplaces, the primary benefit of exchanges is that they save traders the cost of independently searching for someone on the other side of the transaction. ${ }^{9}$ A competitive broker or arbitrager in

- See NYSE News Release, NYSE Directors Approve Amendment to Allow Dual Classes of Common Stock for Listed Companies (July 3, 1986); Impact of Corporate Takeovers, Testimony of the NYSE to the Securities Subcommittee of the Senate Committee on Banking, Housing, and Urban Affairs, 99th Cong., 1st Sess., 1110-1234 (June 12, 1985); NYSE News Release, New York Stock Exchange Reaffirms Commitment to the Highest Standards of Corporate Democracy (May 22, 1985).

- There is little fundamental difference between the economic role of a stock exchange and that of any ordinary shopping center or flea market. All facilitate trading by bringing 
the market demands less of a discount when purchasing a security and charges less of a premium when selling a security if, on average, he does not have to hold it in inventory for very long or incur large search costs to find buyers and sellers. The lower costs are reflected in low bid/ask spreads and high liquidity.

A related benefit is that organized exchanges provide a forum that allows customer orders to be executed with minimum delay. Thus brokers can usually execute a customer's order quickly because the exchange provides swift access to other buyers and sellers. This immediacy is extremely important for purchasers and sellers of securities since prices can move between the time of the order and the time the transaction is consummated. By providing liquidity, exchanges minimize the risk of price fluctuations borne by investors during trading delays.

In addition to providing a centralized location or electronic system to facilitate trades of securities, exchanges provide a set of ancillary services. For example, exchanges police the conduct of member firms to ensure that they are adequately capitalized, do not act fraudulently toward consumers, or otherwise act in ways that harm the reputation of the exchange. Exchanges also may promulgate rules for listed firms governing financial disclosure, annual meetings, or corporate structure.

Exchanges market these transaction and ancillary services by selling access to a trading floor or to an electronic quotation system. The NYSE is run for profit and access to the system is available to members holding one or more of a limited number of seats (and in recent years a small number of nonmembers). The AMEX and regional exchanges are organized along similar lines. The "over-the-counter" NASDAQ trading system, by contrast, is owned by the NASD, a non-profit organization, which places no limits on the number of members and charges members fees depending on the level of services they select from the electronic quotation and trading system.

The value of access to an exchange is a function of the commission income (and trading profits) that can be earned by members. This income is in turn a function of the ability of the exchange to attract listings and facilitate trading of securities of listed companies. The higher the quality of transactional and ancillary services (at a given cost) the more listings will occur and the more investors will be willing to trade. For this reason, exchanges 
have strong incentives to provide transactional and ancillary services that are in the best interests of investors.

In this sense, exchanges face the same incentives to provide high-quality products (i.e., transactional services) as any other business. Just as a manufacturer of automobiles has strong incentives to make a product that consumers want in order to maximize its profitability, an exchange has incentives to design transactional and ancillary services that investors prefer. ${ }^{10}$

\section{B. The Incentive of Exchanges to Adopt Voting Rules that Maximize Investors' Welfare}

The choice of which, if any, voting rules to implement is one of countless decisions exchanges must make in designing customer services. Exchanges have strong incentives to make these decisions-including those about voting rules-in investors' best interests to maximize their own profitability. ${ }^{11}$ In addition to these incentives, certain characteristics of exchanges and voting rules ensure that exchanges will not be able to fool investors into believing they are purchasing high-quality transactional services when they are in fact buying services of poor quality. ${ }^{12}$ These characteristics can be summarized as follows:

1. Observability. The more observable a particular product characteristic, the less likely consumers will be fooled. It is extremely difficult to deceive consumers with respect to the number of rooms in a house, for example, because consumers can ascertain the truth by counting the rooms themselves. At the other extreme are product characteristics that are very difficult to observe. A representation by an automobile mechanic that a given part should be replaced once the car has been taken in for other work, for exam-

10 The analogy between exchanges and other types of sellers is developed in Daniel $R$. Fischel and Sanford J. Grossman, Customer Protection in Futures and Securities Markets, 4 J. Futures Markets 273 (1984).

11 This conclusion does not depend on whether the market for exchanges is competitive. Monopolists, like firms operating in competitive markets, have incentives to offer the level of quality that consumers demand. See id. at 283.

12 There is now a large body of literature on what conditions will facilitate informed judgments by consumers or investors as to product quality. See, e.g., Daniel R. Fischel, Regulatory Conflict and Entry Regulation of New Futures Contracts, 59 J. Bus. 85 (1986); Frank H. Easterbrook and Daniel R. Fischel, Mandatory Disclosure and the Protection of Investors, $70 \mathrm{Va}$. L. Rev. 669 (1984); Alan Schwartz and Louis L. Wilde, Intervening in Markets on the Basis of Imperfect Information: A Legal and Economic Analysis, $127 \mathrm{U}$. Pa. L. Rev. 630 (1979); Phillip Nelson, Advertising as Information, 82 J. Pol. Econ. 729 (1974); Michael R. Darby and Edi Karni, Free Competition and the Optimal Amount of Fraud, 16 J. L. \& Econ. 67 (1973); Richard A. Posner, Regulation of Advertising by the FTC (1973). 
ple, is notoriously difficult to verify at low cost. As a result, the probability that consumers will be misled in this situation is much higher than in the matter of house size.

In terms of observability, the choice of voting rules is much closer to house size than to the condition of automobile parts. The rules chosen by a particular exchange are a matter of public record and thus completely observable. ${ }^{13}$ Accordingly, it is unlikely that exchanges will be able to dupe investors by implementing voting rules that operate to their detriment.

2. Reputation of the seller. The greater a seller's stake in maintaining a reputation for honesty and fair dealing, the less likely the seller will engage in deceptive practices. A well-established large department store is less likely to misrepresent product quality than a transient street vendor selling the same product.

Organized exchanges have strong incentives to maintain good reputations. The long-run profitability of an exchange is highly dependent on trading volume, which will fall if consumers doubt the exchange's integrity. It is clearly in the interest of exchanges to promote consumer confidence by policing abuses by members that cause investors to lose money-at least to the extent that policing is economically feasible. Accordingly, it is in the interest of exchanges to choose voting rules that prevent investors from being exploited. If voting rules allowed by an exchange produced systematic exploitation of investors, investors would lose confidence in the exchange, and the exchange would lose trading volume as investors took their business elsewhere.

3. Repeat transactions. Maintaining a good reputation is most important when repeat transactions are contemplated: the more important future business is, the greater the costs are of losing it through damage to reputation. Victims of abusive practices are not likely to be repeat players in the same game. An organized exchange, by definition, is dependent on repeat business for survival; it is thus less likely to abuse investors.

4. The Role of informed investors. Informed traders or consumers reduce the probability that an exchange or other type of seller will be able to misrepresent product quality. If an exchange adopts voting rules detrimental to investors, informed traders may refuse to transact at all (which may cause the exchange to fail) or

13 It makes no difference whether all investors are aware of the voting rules of an exchange. So long as a sufficient number of investors are aware of the rule, its effects will be reflected in prices and the exchange will behave as if everyone were informed. See note 14 and accompanying text below. 
only transact on terms that reflect the probability of the abusive practice (which would reduce the exchange's profitability). Because uninformed market participants commonly transact on the same terms as those who are informed, the uninformed will be protected by the monitoring of exchange rules by the informed-including rules governing voting rights.

Therefore, the relevant inquiry in assessing the need for regulatory intervention in the choice of voting rules is not whether all investors are informed; rather, it is whether enough are informed so that the exchanges act as if all investors are informed. ${ }^{14}$ Institutional investors, financial intermediaries, and wealthy individuals are responsible for a high (and increasing) percentage of trading on organized exchanges. The actions of these sophisticated market participants-in deciding what securities to purchase and on what terms-lead exchanges to adopt rules that benefit all investors.

5. Competition among sellers. If one exchange were to implement voting rules that harmed investors, other exchanges then would have incentives to correct this mistake to attract listings and volume away from the first exchange. This competitive pressure also creates incentives on the part of exchanges to adopt rules that investors want. ${ }^{15}$

\section{Differences Among Exchanges}

That exchanges have incentives to offer transactional and ancillary services that investors demand does not imply that all exchanges will be identical. On the contrary, it is common in most markets for different firms to cater to a particular group of consumers. The different strategies followed by firms imply nothing more than specialization within a market. The decision to manufacture luxury cars, for example, is not inherently superior to the decision to manufacture compact cars. Differences among exchanges can be analyzed along the same lines. Although the NASD, NYSE, and AMEX all provide transactional and ancillary services, there are differences among them. One such difference is the

${ }^{34}$ For a more general discussion of this point, see Daniel R. Fischel, Use of Modern Finance Theory in Securities Fraud Cases Involving Actively Traded Securities, 38 Bus. L. 1 (1982).

1s With improved technology, the exchanges are now much more competitive than they previously were. See Gary C. Sanger and John J. McConnell, Stock Exchange Listings, Firm Value and Security Market Efficiency: The Impact of NASDAQ, 21 J. Fin. Quant. Anal. 1 (1986); John J. McConnell and Gary C. Sanger, A Trading Strategy for New Listings on the NYSE, Jan.-Feb. 1984 Fin. Anal. J. 34. However, as discussed above at note 11, even a monopolist has strong incentives to offer a level of quality that consumers demand. 
NYSE's historic policy of refusing to list the securities of firms with dual class common stock compared with the opposite policy of the NASD. But this is only one of the many differences. The exchanges also have different listing and delisting standards, as well as different requirements for listed firms. ${ }^{16}$

Probably the most important difference among exchanges is in their trading technologies. The NYSE uses a "specialist system" to match buy and sell orders for each security. The specialist is charged with the responsibility of maintaining an "orderly" market, in addition to acting as a transactional intermediary. In practice this means he attempts to moderate price changes by buying or selling for his own account.

In contrast to the NYSE, the NASDAQ system maintains competitive "market makers." These are firms committed to announcing at all times prices at which they will buy or sell a minimum number of shares of a stock. Decentralized market forces thus ensure that prices will move quickly and accurately to reflect all available information.

The differences among exchanges, however, are becoming increasingly blurred. For example, while the specialist and competitive market maker system appear to be dramatically different, most large trading on both the NYSE and the NASDAQ is done in a nearly identical manner in the "upstairs" market. A broker dealing in a large block of stock will call other dealers and institutions to find one interested in the other end of the deal. The specialist on the floor of the NYSE, the subject of much attention, actually serves as a market maker only for the residual small blocks and odd lots of stock, as well as a backup broker for floor traders.

The governance rules imposed by exchanges also appear to be moving in the same direction. In July of 1985 , for example, the NASD (perhaps in response to regulatory pressure) proposed rules requiring listed firms to have an audit committee and a certain number of independent directors. These requirements are similar to those imposed by the NYSE. In other areas, the NYSE has moved in the direction of the NASD. One example of this development is the abolition of fixed commission rates. ${ }^{17}$ Another example

16 For example, the NYSE generally requires that listing companies have an annual income of at least $\$ 2.5$ million and an aggregate market value of stock that is greater than $\$ 18$ million, with at least 1.1 million public shares held by at least 2,000 investors with 100 or more shares. In contrast, NASDAQ requires only that a firm have $\$ 2$ million in assets, with 100,000 shares held by at least 300 shareholders. See NYSE, Fact Book 35 (1986); NASD, NASDAQ Fact Book 16 (1984).

${ }^{17}$ For a discussion of the deregulation of brokerage commissions, see Gregg A. Jarrell, 
is the suspension by the NYSE of its prohibition of the listing of securities of firms with dual class common stock.

Notwithstanding these developments, basic differences among the exchanges remain. The differences in trading technologies, listing requirements, and governance rules reflect the different strategies of the exchanges. The NYSE has attempted to attract large, mature firms, while the NASD has tailored its NASDAQ system to the needs of smaller, more entrepreneurial firms. The rules and trading technologies of each exchange reflect the set of conditions best suited for the firms listing on the exchange. Since firms issuing stock differ, the best exchange rules for them will differ as well.

\section{The "RAce to the Bottom" Thesis}

Critics of competition among exchanges argue that efforts by exchanges to attract listings leads them to adopt pro-management rules to the detriment of investors. These critics assume that since corporate managers decide whether and where to list, they will base their decision on which exchange offers them the greatest opportunity to exploit investors. If one exchange relaxes its rules, and allows this exploitation to occur, the argument runs, other exchanges will be forced to follow suit to avoid a drain of their listings to the first exchange. The result is a "race to the bottom" in which all exchanges end up with similar (pro-management, antishareholder) rules. ${ }^{18}$.

The argument that competition among lawmaking bodies leads to a "race to the bottom" is not a new one. The identical argument was made in the past to support the replacement of state chartering of corporations by federal chartering. It was in this earlier debate that the phrase "race to the bottom" originated.19 Under a system of state chartering, it was argued, competition among states to attract incorporations causes states to adopt increasingly pro-management, anti-investor rules. The claim was that only federal chartering of corporations or federal legislation setting minimum standards could protect investors from the adverse consequences of "lax" state corporation laws.

In connection with this proposal for federal chartering of corporations, the "race to the bottom" thesis has been vigorously ana-

Change at the Exchange: The Causes and Effects of Deregulation, 27 J. L. \& Econ. 273 (1984).

18 See note 8 and accompanying text above.

10 See William L. Cary, Federalism and Corporate Law: Reflections Upon Delaware, 83 Yale L. J. 663 (1974). 
lyzed and discredited on both a theoretical and an empirical level. ${ }^{20}$ The analogous argument that competition among exchanges in their choice of voting rules is harmful to investors is equally without merit.

\section{A. The Assumptions Underlying the "Race to the Bottom" Thesis}

The argument that competition leads exchanges to adopt antiinvestor rules to attract listings is based on at least three related misconceptions: (1) that managers prefer exchange rules that allow them to exploit investors; (2) that it is in the interests of exchanges to adopt such rules; and (3) that the absence of regulation is necessarily evidence of a pro-management, anti-investor bias. These three misconceptions are discussed below.

1. Managers' incentives. Entrepreneurs or corporate managers who attempt to raise equity capital must convince investors that the securities being sold at the price offered are superior to alternative uses of investment dollars. These alternative uses are almost infinite in number. Investors can purchase equity or debt securities of other firms, put their money in a bank, buy government securities, invest in real estate, purchase gold or other precious metals, and so forth. The greater investors perceive the probability that they will be exploited-that the funds invested will be used to benefit the managers at the expense of investors-the more attractive competing investments will become. Alternatively, investors simply may pay less for securities when they perceive that managers' discretion will be too great.

Thus, in an efficient market it is entrepreneurs seeking to raise capital, and not investors, who bear the costs of inefficient rules that allow investors to be exploited. ${ }^{21}$ The greater the inefficiency, the less willing potential investors will be to invest and the lower

\footnotetext{
${ }^{20}$ See, e.g., Ralph K. Winter, State Law, Shareholder Protection, and the Theory of the Corporation, 6 J. Legal Stud. 251 (1977); Barry D. Baysinger and Henry N. Butler, The Role of Corporate Law in the Theory of the Firm, 28 J. L. \& Econ. 179 (1985); Roberta Romano, Law as a Product: Some Pieces of the Incorporation Puzzle, 1 J. L. Econ. \& Org. 225 (1985); Peter Dodd and Richard Leftwich, The Market for Corporate Charters: "Unhealthy Competition" versus Federal Regulation, 53 J. Bus. 259 (1980); Daniel R. Fischel, The "Race to the Bottom" Revisited: Reflections on Recent Developments in Delaware's Corporation Law, 76 Nw. U. L. Rev. 913 (1982). But see Jonathan R. Macey and Geoffrey P. Miller, Toward an Interest Group Theory of Delaware Corporate Law, 65 Tex L. Rev. (forthcoming 1987) (arguing that managers have some very limited discretion to act to the detriment of investors in choosing a state of incorporation).

${ }^{21}$ Michael C. Jensen and William H. Meckling, Theory of the Firm: Managerial Behavior, Agency Costs, and Ownership Structure, 3 J. Fin. Econ. 305 (1976).
} 
the price investors will be willing to pay. This will increase the entrepreneurs' cost of capital but will not harm investors who discount the inefficiency by paying a lower price.

To decrease their cost of capital, entrepreneurs have strong incentives to adopt rules or governance mechanisms that allay investors' concerns. These rules or governance mechanisms can take a variety of forms as will be demonstrated in part IV below. Managers also have strong incentives to decide where to incorporate based on which set of state laws is suitable for the particular needs of their firm. Similarly, they will decide whether and where to list based on which exchange will further the interests of their investors. Entrepreneurs have every incentive to adopt rules, including the decision of which exchange rules to be governed by, in the best interests of investors in order to lower their cost of capital.

The logical fallacy in the "race to the bottom" thesis is that it assumes that managers will seek exchanges that facilitate the exploitation of investors. This strategy will only work if investors as a class are irrational or completely ignorant. Why else would investors, notwithstanding the virtually infinite number of investment alternatives, continue to entrust their money to managers who seek rules that allow investors to be exploited? The assumption that investors as a class are completely ignorant or irrational, however, is implausible in light of the observability of exchange rules and the increasing dominance of institutional investors and financial intermediaries. Once investors as a class are assumed to be rational, the incentive of managers to choose exchanges that maximize, not minimize, investors' welfare in order to lower their cost of capital is compelling. And competition among exchanges, by providing managers with more choices in choosing an exchange with rules suited to the needs of a particular firm, allows the cost of capital to be lowered further.

2. The Incentives of exchanges. Even if we assume that the managers of some firms intend to expropriate the wealth of their stockholders, it still does not follow that it is in the interest of the exchange to allow this expropriation to occur. Exchanges do not compete for listings per se, but rather seek to maximize the volume of trade, which is a function of the number of listings and the amount of trading in listed securities. As we saw above, it is not in the best interest of the exchange to allow exploitation of investors.

If an exchange allows managers of some firms to exploit investors, investors will lose confidence in the exchange, as a whole, causing all firms on the exchange to face higher costs of capital. This in turn will decrease the amount of listings in the future and 
thus also will reduce the amount of trade. Loss of confidence in the exchange also will lead to a decline in the value of currently listed securities. A decline in the value of listed securities, like a decline in the amount of trade, will decrease income from commissions. And any action that decreases commission income will decrease the value of membership on the exchange. Thus, any decrease in the amount of trade or value of securities listed on the exchange reduces the wealth of member firms. Once again, it is clear that the profit-maximizing strategy for an exchange is to promulgate rules that maximize, not minimize, investors' welfare.

3. The relationship between regulation and investors' welfare. A final misconception accompanying the "race to the bottom" thesis is that it is possible to identify the "bottom" by determining which jurisdiction or exchange is the least regulatory. But to equate the level of investor protection with the amount of regulation is a serious error. Consumers or investors do not necessarily benefit from regulation. ${ }^{22}$

For example, few today would argue that the NYSE was alone in protecting investors because it had a policy of fixed commission rates while the other exchanges did not. ${ }^{23}$ Nor would many argue that the abolition of this regulation-which was justified in large part as a device to protect investors and which was abandoned as a result of competition from other markets-represented an example of the race to the bottom. Similarly, the fact that one exchange has, for example, stricter disclosure requirements may mean that investors of firms on that exchange must bear costs of regulation that exceed its benefits, costs not borne by investors of firms on other exchanges. If competition in this situation forces the first exchange to drop the regulation, investors benefit. ${ }^{24}$

The inaccuracy of equating regulation with the protection of

${ }^{22}$ Several economists have concluded that the widespread assumption that investors have benefited from securities regulation is not supported by the empirical evidence. See, e.g., Susan M. Phillips and J. Richard Zecher, The SEC and the Public Interest (1981); Greg A. Jarrell, The Economic Effects of Federal Regulation of the Market for New Security Issues, 24 J. L. \& Econ. 613 (1981); George J. Benston, Required Disclosure and the Stock Market: An Evaluation of the Securities Exchange Act of 1934, 63 Am. Econ. Rev. 132 (1973); George J. Stigler, Public Regulation of the Securities Markets, 37 J. Bus. 117 (1964). For the opposite perspective, see Irwin Friend, Economic and Equity Aspects of Securities Regulation (Working Paper No. 7-82, Rodney L. White Center for Financial Research, University of Pennsylvania 1982). For a review of this evidence, see Easterbrook and Fischel, 70 Va. L. Rev. 669 (cited in note 12). On the economics of regulation generally, see Stephen Breyer, Regulation and Its Reform (1982).

2s See Jarrell, 27 J. L. \& Econ. at 276 (cited in note 17).

24 Conversely, competition among exchanges in other situations may force exchanges to adopt regulations. 
investors is further demonstrated by two related factors that have special relevance to dual class voting. ${ }^{26}$ First, particular regulations can have mixed effects. A prohibition of dual class voting may protect investors in some instances yet harm them in others. Whether a prohibition is desirable depends in large part on a weighing of these costs and benefits. For the reasons discussed above, exchanges have strong incentives to weigh these costs and benefits and strike the appropriate balance.

Second, no reason exists to believe that one type of regulation is optimal for all firms. Some types of firms might benefit from rules allowing dual class common stock while others might not. Just as we observe successful firms incorporated in jurisdictions with strict state laws and equally successful firms incorporated in jurisdictions with liberal state laws, so too may firms listed on exchanges with one set of governance rules be as successful as firms on exchanges with another set of governance rules. Both types of exchanges may be optimal for the firms choosing to list on them.

\section{B. The Empirical Evidence}

Proponents of the "race to the bottom" thesis assume that managers' decisions to list on exchanges that prohibit dual class common stock (or are more regulatory in other ways) will benefit investors. Analogously, proponents of this thesis in the state chartering debate assume that incorporation in Delaware, the jurisdiction that for decades afforded managers the greatest discretion, will harm investors.

These are testable propositions. If the hypothesis that the rules of enabling jurisdictions such as Delaware are promanagement and anti-investor is correct, then firms that reincorporate in Delaware should experience lower stock prices. The evidence, however, is to the contrary. ${ }^{26}$ Similarly, if the NYSE protects investors while other exchanges do not, the decision by firms to switch their listing to the NYSE should be perceived as good news by investors.

Numerous studies have attempted to measure the gains, if any, from listing on the NYSE rather than being traded over the counter or listed on other exchanges. ${ }^{27}$ After adjusting for move-

25 Both of these factors are discussed in greater detail in part III below.

28 See Dodd and Leftwich, 53 J. Bus. at 261 (cited in note 20); Romano, 1 J. L. Econ. \& Org. at 255 (cited in note 20); Baysinger and Butler, 28 J. L. \& Econ. at 188 (cited in note 20).

${ }^{27}$ See, e.g., Sanger and McConnell, 21 J. Fin. Quant. Anal. 1 (cited in note 15); Louis W. Ying, Wilbur G. Lewellen, Gary G. Schlarbaum, and Ronald C. Lease, Stock Exchange 
ments in the overall market, these studies generally find that firms newly listed on the NYSE tend to have abnormally favorable performance in the months prior to the announcement to list, normal performance at the time of announcement, abnormally positive performance between the announcement and the eventual listing, and abnormally negative performance after listing.

Overall, this combination of normal, positive, and negative performance for different periods surrounding the listing decision suggests that the evidence does not point unambiguously to any conclusion on the effect of listing on the NYSE on investors' wealth. The absence of a statistically significant positive reaction to the announcement to list on the NYSE, ${ }^{28}$ the most direct test of how investors perceive the change in listing, only reinforces this conclusion.

The inconclusive nature of the empirical results has significant implications for the "race to the bottom" thesis. Proponents of the thesis assume that the NYSE is a haven for rules that protect stockholders, and that the other exchanges are the "bottom" because they do not have these protective rules. If this were true, we would expect that rational investors would be willing to pay significantly more for a stock that listed on the NYSE. This proposition is not supported by the existing evidence.

Two caveats are in order. First, the evidence must be interpreted with considerable caution because it is impossible to disentangle investors' perceptions of the differences in trading technologies from their perceptions regarding governance rules. Second, the immense success of the NYSE over long periods of time suggests that there must be benefits to listing there for many firms-notwithstanding the inconclusive findings of studies to date. Of course, the identical point can be made in connection with the NASDAQ system, which also has enjoyed spectacular success. Both exchanges appear to be providing transactional and ancillary services that are well suited to the needs of their respective firms.

Listings and Securities Returns, 12 J. Fin. Quant. Anal. 415 (1977); James C. Van Horne, New Listings and Their Price Behavior, 25 J. Fin. 783 (1970). See also McConnell and Sanger, Jan.-Feb. 1984 Fin. Anal. J. 34 (cited in note 15).

${ }^{28}$ Sanger and McConnell test whether the effect of listing on the NYSE has changed after the introduction of the NASDAQ system. They find that price response to the announcement to list on the NYSE is positive before and after the introduction of NASDAQ, but statistically significant only in the pre-NASDAQ period. Sanger and McConnell, $21 \mathrm{~J}$. Fin. Quant. Anal. at 22 (cited in note 15). They conclude that the superiority of the NYSE in providing transactional services has diminished significantly with the introduction of NASDAQ. Id. at 22-23. 


\section{Dual Class Common Stock and the Economics of SHAREHOLDER VOTING}

In designing a firm's capital structure, managers must choose voting rules. This section discusses the economics of shareholder voting and the criteria that determine whether a rule of one share, one vote or dual class voting is optimal for a particular firm. It also summarizes the empirical evidence regarding the costs and benefits of dual class voting.

\section{A. Voting as a Monitoring Mechanism}

Publicly held corporations are characterized by a separation of the functions of management and risk bearing. This separation enables skilled managers to run businesses-even though they lack the personal wealth to finance all of the firm's investment projects; it also enables those who have wealth to invest it-even though they lack managerial skills. This specialization of function also enables investors to diversify their portfolios, thus reducing risk and making investment more attractive.

While the separation of management and risk bearing allows investors to capture the benefits of specialization of function, it also exposes them to the risk that their funds will be used for managers' personal benefit. Market forces such as competition in product and labor markets limit the ability of managers to engage in behavior that does not maximize the wealth of the firm ${ }^{29}$-although they do not eliminate it entirely. In anticipation of the prospect of such behavior, investors will discount the price they are willing to pay for shares. To minimize the size of this discount, those who raise capital have incentives to establish institutional arrangements whereby the performance of managers is continually monitored.

Voting rules are one type of monitoring mechanism. ${ }^{30}$ The right to vote provides shareholders with the opportunity to decide whether their agents have performed well enough to continue in office. Typically, voting rules also force managers to obtain the approval of investors for certain fundamental decisions such as mergers or amendments to the corporate charter. Thus, the right to vote acts as a constraint on the ability of managers to take actions

20 See Eugene F. Fama, Agency Problems and the Theory of the Firm, 88 J. Pol. Econ. 288 (1980).

so For a more complete discussion of voting as a monitoring mechanism, see Frank H. Easterbrook and Daniel R. Fischel, Voting in Corporate Law, 26 J. L. \& Econ. 395 (1983). 
that harm investors.

But voting is a very imperfect monitoring mechanism. Many shareholders are passive investors who hold many different investments. They have little interest in managing the firm and insufficient incentive to learn the details of management. Moreover, any attempt by shareholders to monitor managers is likely to fail because of the serious problems of collective action and free riders. No shareholder can capture the full gains from monitoring a firm's managers. The benefits from such monitoring efforts will accrue to investors according to the size of their holdings, not according to their monitoring efforts. Because other shareholders can take a free ride on the monitoring efforts of any one shareholder, no individual shareholder has much of an incentive to expend resources in monitoring managers. As a result, shareholders routinely vote for incumbent managers and approve management-sponsored initiatives in all but the rarest of cases.

The one important exception where voting does matter is in contests for corporate control-mergers, proxy fights, or tender offers. Contestants in the market for corporate control typically accumulate large blocks of stock; this in turn reduces the free rider problem. Holders of large blocks of shares have a sufficient interest in the firm to participate actively in management decisions and to terminate managers who are behaving inefficiently. The ability to vote, and thereby control who will manage the firm's assets, is fundamental to the incentive to acquire large blocks of shares in battles for corporate control.

Many other forms of monitoring arrangements exist. ${ }^{31}$ Examples are the sale of securities through investment bankers, the retention of third-party accountants to verify financial statements, and the use of independent directors. Still another method of monitoring is to tie managerial compensation to firm performance. This can be accomplished if managers own a large percentage of the outstanding stock or if changes in compensation are linked to the success of the firm.

Rules, whether a product of state law, federal law, or exchange rules, also can minimize divergences of interest between managers and investors. Such rules are beneficial when they economize on the cost of contracting. The economic justification for the rule

s1 These alternative monitoring arrangements are discussed at length in Daniel R. Fischel and Michael Bradley, The Role of Liability Rules and the Derivative Suit in Corporate Law: A Theoretical and Empirical Analysis, 71 Cornell L. Rev. 261 (1986); Easterbrook and Fischel, 70 Va. L. Rev. 669 (cited in note 12). 
against fraud, for example, is that it saves the parties the costs of negotiating and drafting contractual provisions to prohibit the practice.

Significantly, all of these monitoring mechanisms impose costs as well as create benefits. Independent directors, for example, are likely to be more impartial but also less competent. In some cases, the costs of less informed and more bureaucratic decision making may exceed the benefits of greater impartiality. Similarly, strict legal or exchange rules may limit self-dealing but in the process stifle a large number of beneficial transactions. Because monitoring mechanisms are costly, no presumption should exist that they are always beneficial or that they will be used by all firms in identical proportions.

Thus, some firms may rely heavily on independent directors; others, on closely linking managerial compensation to the performance of the firm's outstanding securities; and still others, on locating in a jurisdiction with more stringent regulation. Each of these decisions may be optimal for different firms. Similarly, the importance of the market for corporate control as a monitoring mechanism may vary for different firms. The choice between a rule of one share, one vote and dual class common stock depends in large part on the importance of the market for corporate control as a monitoring device for a particular firm.

\section{B. The Rule of One Share, One Vote}

The vast majority of publicly held corporations have limited the right to vote to shareholders (except in situations of financial distress) and have attached one vote to every share. This is true for firms regardless of where they are listed, even though firms listed on the AMEX or the NASDAQ system could have chosen an alternative rule.

Shareholders (rather than, say, employees or creditors) typically have the right to vote because they are the group with the best incentives (collective action problems to one side) to maximize the value of the firm. As residual claimants to the firm's income, shareholders receive most of the marginal gains and incur most of the marginal costs from decisions made about how the firm's assets should be deployed. Thus they will be most directly affected by managerial decisions that change the value of the firm. Those with fixed claims, such as debtholders, by contrast, are only concerned about the probability of bankruptcy. As a result, debtholders' incentives to maximize the value of the firm generally will be inferior to those of shareholders. 
While shareholders as a class typically have the best incentives to maximize firm value, not all shareholders are identical. Those with a large stake in the venture have much better incentives than those with a tiny stake because they reap more of the gains and bear more of the costs from abnormally good or bad performance. The rule of one share, one vote reflects this economic reality by assigning votes, and thus the ability to monitor the managers, in direct proportion to shareholders' stake in the venture.

In most cases, the collective action problem faced by dispersed shareholders renders voting relatively ineffective as a monitoring mechanism. Nevertheless, managers realize that they are being monitored by those who have the best incentives (that is, the largest stakes), and also realize that the collective action problem can be overcome at any time by the accumulation of shares and exercise of the attached votes. Managers' knowledge that they can be ousted by the exercise of these votes provides them an incentive to maximize the value of the firm.

\section{Dual Class Common Stock and Economic Incentives}

The one share, one vote rule enhances voting as a monitoring mechanism because it facilitates transfers of control. Dual class common stock, by contrast, makes hostile takeovers-one type of transfer of control-more difficult because it allows insiders to hold 51 percent of the votes without holding 51 percent of the equity. For a given equity base, then, insiders must commit a smaller fraction of their own wealth to retain a controlling interest in the firm.

For this reason, the question why firms adopt dual class common stock breaks down into two questions. First, is it efficient for insiders in some cases to retain control? Second, is it ever efficient for insiders to retain control by holding 51 percent of a superior voting stock rather than holding 51 percent of the entire equity base? These questions are discussed below.

1. The value of control to insiders. Managers of a particular firm may desire to retain control for several reasons that are entirely consistent with the goal of maximizing the shareholders' wealth. First, insiders may simply value control more than outsiders. This explains why family-run firms or firms still controlled by the founding entrepreneur often issue dual class common stock or are reluctant to issue new equity when doing so would dilute their 
own holdings. ${ }^{32}$ It is even possible that the market value of the shares of such firms would be higher if the family or founding entrepreneur would relinquish control. In this event, the family or entrepreneur is paying for its preference for control in the form of a higher cost of capital. Of course, the opposite can also be true. The market value of shares in a firm controlled by a family or founding entrepreneur may be higher if, for example, continuity of management is valued by investors and there exist alternative governance mechanisms to align the interests of managers and investors.

Second, insider control may increase managers' incentives to invest in firm-specific human capital. ${ }^{33}$ Managers frequently must invest their own time and resources to gain knowledge concerning a particular firm's investment opportunities, personnel, specific practices, and organization. Once acquired, these skills are specific to the particular firm. Firm-specific skills, in turn, make managers who acquire them more valuable to their particular firm than to firms generally. Managers' incentive to acquire these firm-specific skills results from the expectation that they will continue to be employed by their firm for a long period and thus obtain a return on their investment.

Stockholders also benefit from the acquisition of firm-specific skills, since managers who possess them make the firm more valuable. However, managers always run the risk that they will be terminated by shareholders or, more realistically, by a purchaser of control who might change the use of the firm's assets. The greater the managers' perceived probability that they may be denied a return on their firm-specific investments, the less willing they will be to make them in the first place. Shareholders and managers will both be worse off in this event, as there will be fewer returns on firm-specific investments to share.

One method of assuring managers that their firm-specific investments will not be appropriated is to allow insiders to retain control. This is not the only method. Consider, for example, golden parachutes. The difference between insider control and golden parachutes is that insider control protects managers from transfers

s2 See Harry DeAngelo and Linda DeAngelo, Managerial Ownership of Voting Rights, 14 J. Fin. Econ. 33 (1985).

ss See, e.g., Benjamin Klein, Robert G. Crawford, and Armen A. Alchian, Vertical Integration, Appropriable Rents, and the Competitive Contracting Process, 21 J. L. \& Econ. 297 (1978); Oliver E. Williamson, Transaction-Cost Economics: The Governance of Contractual Relations, 22 J. L. \& Econ. 233 (1979). 
of control while golden parachutes compensate them in the event a transfer occurs. Both techniques have costs and benefits as methods of protecting firm-specific investments.

Golden parachutes may be difficult (costly) to negotiate, and their enforceability is suspect. They also create a moral hazard. If managers believe they will be compensated when a transfer of control occurs, they may take actions, such as running the firm inefficiently, to increase the probability of such an event. Insider control, by contrast, denies shareholders the ability to receive control premiums and also denies them the ability to share in the gains created by the transfer of assets to more highly valued uses. Notwithstanding these costs of golden parachutes and insider control, one or both techniques may be beneficial in particular cases to protect firm-specific investments.

The third possible benefit of insider control is that it decreases the need for managers to expend resources to convince potential bidders for control that the current use of the firm's assets is optimal. ${ }^{34}$ In situations of asymmetric information-where managers have information that outside investors do not-managers may have to employ costly signaling devices to communicate their private information. Examples of such signaling devices include high debt-equity ratios, dividend changes, and share repurchases. ${ }^{35}$ The need to convince outsiders not to attempt a transfer of control also may affect investment decisions. Managers may choose more "visible" projects rather than more valuable projects whose value is too difficult to communicate. If insiders control the firm, these costs need not be incurred.

Fourth, insider control may allow shareholders of a target corporation to obtain a higher price when a transfer of control does occur. One difficulty that dispersed shareholders face when confronted with a hostile tender offer is that they are unable to act collectively. This inability to coordinate makes it impossible for shareholders to negotiate with the bidder to obtain a better price. Insider control is a device that overcomes this collective action problem among the shareholders. Its effect is to force potential acquirors to deal directly with management, who in turn can negoti-

34 See DeAngelo and DeAngelo, 14 J. Fin. Econ. at 33 (cited in note 32).

35 See, e.g., Ronald W. Masulis, The Effects of Capital Structure Change on Security Prices: A Study of Exchange Offers, 8 J. Fin. Econ. 139 (1980). For a sampling of the large economic literature on signaling, see John G. Riley, Competitive Signalling, 10 J. Econ. Theory 174 (1975); Michael Spence, Job Market Signaling, 87 Quart. J. Econ. 355 (1973); Joseph E. Stiglitz, The Theory of "Screening," Education, and the Distribution of Income, 65 Amer. Econ. Rev. 283 (1975). 
ate on behalf of all shareholders. Granting insiders what amounts to a veto power over transfers of control is likely to decrease the number of control transactions but increase the price paid per transaction. Such action is likely to reduce the wealth of potential bidders-and perhaps, even shareholders as a class-but may be rational behavior for shareholders of a particular firm. ${ }^{36}$

2. Dual class voting as a mechanism for preserving insider control. If every share is entitled to one vote, insiders can retain control of a firm by holding 51 percent of the outstanding equity. Why would insiders eschew this alternative in favor of dual class common stock? One reason is that insiders may simply lack the personal wealth to maintain 51 percent ownership when the value of the outstanding equity becomes sufficiently large. Indeed, the magnitude of most publicly held corporations greatly exceeds the magnitude of most personal fortunes. Outside equity enables the firm to pursue investment opportunities that have expected returns higher than alternative uses of capital regardless of the size of insiders' wealth.

Even an owner/manager who has sufficient personal wealth to purchase 51 percent of the outstanding equity may prefer not to do so. Outside investors with access to capital markets can diversify risk more efficiently than insiders who already have a large percentage of their wealth tied up in their firm in the form of their human capital. Diversified investors in effect charge a lower price to bear risk than would a less diversified owner/manager. ${ }^{37} \mathrm{Al}$ lowing these more efficient, outside risk bearers to share the risk lowers the cost of risk to the firm.

This risk sharing arrangement between owner/managers and outside investors benefits managers and stockholders, and also society as a whole. Society benefits because profitable investment opportunities are pursued even if they are risky or will not generate cash flows until sometime in the future. Owner/managers who finance projects with their personal wealth, by contrast, will tend to choose less risky projects-even if they have a lower present value-because of their inability to diversify. Similarly, owner/

36 On the tension between which strategy is optimal for a particular firm and which is optimal for shareholders as a whole, see Sanford J. Grossman and Oliver D. Hart, Takeover Bids, the Free-Rider Problem, and the Theory of the Corporation, 11 Bell J. Econ. 42 (1980); Frank H. Easterbrook and Daniel R. Fischel, Auctions and Sunk Costs in Tender Offers, 35 Stan. L. Rev. 1 (1982).

37 Eugene F. Fama and Michael C. Jensen, Agency Problems and Residual Claims, 26 J. L. \& Econ. 327 (1983); Eugene F. Fama and Michael C. Jensen, Organizational Forms and Investment Decisions, 14 J. Fin. Econ. 101 (1985). 
managers will tend to choose projects that produce returns during their tenure with the firm-even if these projects have a lower present value than projects with more extended payoffs. The tendency of firms financed with equity ${ }^{38}$ to choose investment projects under the market value rule-to choose those projects with the highest net present value-increases the production of goods and services in the economy as a whole.

Dual class common stock allows insiders to obtain the benefits of outside equity financing while still retaining control over the firm. This is not to suggest that all firms should employ dual class common stock. The cost of dual class common stock is that the effectiveness of the market for corporate control as a monitoring device is reduced. Whether this substantial cost is outweighed by the benefits of dual class voting is an empirical question that is discussed below.

3. Other uses of dual class common stock. Dual class common stock is employed for reasons other than making transfers of control more difficult. General Motors' new classes of $\mathbf{E}$ and $\mathrm{H}$ stock are examples of dual class common stock with a completely different purpose. The dividends and other distributions to the holders of these stocks are tied to the performance of acquired divisions, and so the prices of these stocks reflect the prospects of these divisions rather than the whole of the firm. In addition, holders of these shares have inferior voting rights to those of stockholders in General Motors. Because the value of these stocks is tied to particular divisions of General Motors rather than General Motors as a whole, their holders have less incentive to monitor the management of General Motors. Inferior voting rights reflect this decreased incentive to monitor management relative to other shareholders of General Motors.

\section{Dual Class Common Stock and Corporate Democracy}

Some may argue that unequal voting rights are undesirable because they are inconsistent with the principle of "corporate democracy." This argument, however, is fundamentally flawed. All firms, including corporations, consist of contractual relationships freely entered into by economic actors to maximize their joint welfare. Who has the right to vote and how and when the vote can be exercised are rights that are typically allocated by contract. In con-

${ }^{38}$ I do not discuss here the costs and benefits of debt financing. For a discussion, see Jensen and Meckling, $3 \mathrm{~J}$. Fin. Econ. 305 (cited in note 21). 
trast to governmental democracies-which are usually designed to serve broader goals than wealth maximization-the optimal voting rules for any particular firm are those that maximize its value.

Two important implications follow from this insight. First, no reason exists to believe that the optimal voting rules for publicly held corporations engaged in the production of goods and services will be identical to the voting rules for representative governments. Indeed, there is little similarity between the voting rules for the two institutions. For example, most corporate actors-employees, bondholders, suppliers, preferred stockholders, and managers-have no votes even though they all are investors in the firm. For common stockholders, the group that does vote, the most common structure is one share, one vote-not one person, one vote as in the political context. Thus votes in the corporate, but not political, context are typically assigned by reference to the extent of property ownership. Just as there is no reason to believe that votes in the political arena should be assigned according to wealth, so there is no reason to believe that principles from political democracy should serve as a model for corporate governance.

The second implication that follows from the economics of voting rules is that the rules for all firms need not be identical. The optimal voting rule depends on which rules will maximize the value of the firm; different rules may be optimal for different types of firms. Participants in general partnerships, for example, typically have equal votes while most participants in limited partnerships have no votes. Similarly, the voting rights of investors in dual class firms differ from those of investors in firms with only one class of common stock. These observed differences in voting rights may reflect differences in optimal voting rules for different firms.

Moreover, differences in nominal voting rights understate differences across firms in effective voting rights. ${ }^{39}$ Effective voting rights depend on the concentration of the ownership of votes. For example, the holder of 10 percent of the outstanding shares of a publicly held corporation that has the rule of one share, one vote may have very powerful voting rights if shares are widely dispersed, but virtually no power if there is another shareholder who owns 51 percent of the outstanding shares.

Contractual arrangements also may affect voting rights. Cumulative voting, voting trusts, and standstill agreements are all examples of arrangements that, like dual class common stock, have

30 The differences between nominal and effective voting rights are emphasized in DeAngelo and DeAngelo, 14 J. Fin. Econ. 33 (cited in note 32). 
the effect of altering effective voting rights. Holding companies can have a similar effect. For example, consider an investor who owns 50.1 percent of the votes of a holding company, which in turns owns 50.1 percent of the votes of another firm. Under a rule of one share, one vote, such an investor has effective control over the subsidiary firm with only about a 25 percent interest in its cash flows.

In sum, it is not unusual for different types of firms to have different voting rules. Nor is it unusual for effective voting rights to differ across firms that all of which nominally have a rule of one share, one vote. All of these arrangements-as well as the rule of one share, one vote itself-are inconsistent with the political model of one person, one vote. Dual class common stock is simply another form of voting arrangement that affects effective voting rights. The misguided analogy to political democracy provides no basis for prohibiting dual class common stock, or any other voting rule, that has the effect of maximizing the value of certain firms.

\section{E. Dual Class Common Stock: The Evidence}

1. Characteristics of firms with dual class common stock. A small percentage of publicly traded firms employ dual class common stock; that percentage has fluctuated over time but has not grown appreciably larger. ${ }^{40}$ The small number of firms that have dual class common stock is significant. The NASD, AMEX, and the laws of most states permit the listing of dual class common stock. Thus the fact that most firms utilize the rule of one share, one vote strongly suggests that dual class common stock is not optimal for the vast majority of publicly held firms. At the same time, the fact that the rule of one share, one vote is desirable for most firms does not mean it is desirable for all firms.

A number of researchers have studied the types of firms that

40 Indeed, there were more dual class firms in 1970 than in 1980 and more still in 1960. The decrease in dual class firms over this period is a result of both acquisitions and expiration of the time period for dual class common stock as stipulated in corporate charters. Recently, however, the use of dual class common has become somewhat popular. Since 1980, at least 37 firms have issued limited voting stock, and 23 of these occurred in 1983 or 1984. See M. Megan Partch, The Creation of a Class of Limited Voting Common Stock and Shareholder Wealth, J. Fin. Econ. (forthcoming 1987) (table 1). As of October, 1985, approximately 100 of the slightly over 4,000 companies traded on NASDAQ (or about 2.5 percent) had multiple classes of common stock. As of July, 1984, approximately 50 of the over 900 firms listed on the American Stock Exchange (or about 6 percent) had two or more classes of common stock outstanding. A handful of firms listed on the NYSE also have adopted dual capitalization pending resolution of the controversy over listing standards on the NYSE. See DeAngelo and DeAngelo, 14 J. Fin. Econ. at 54 (cited in note 32). 
have adopted dual class common stock. ${ }^{41}$ These studies reveal that firms that adopt dual class common tend to have certain common and related characteristics. First, managers of dual class firms (defined as corporate officers and their families) tend to own approximately 55 percent of the voting rights. ${ }^{22}$ Indeed, one motivation for recapitalizations appears to be the desire to obtain voting control. Thus management ownership of voting rights is significantly greater after recapitalizations than before. ${ }^{43}$ Second, managers of dual class firms own a greater percentage of votes than rights to cash flows. Nevertheless, managers tend to have a significant equity stake in the firm; the median cash flow interest is 24 percent. ${ }^{44}$ Third, dual class firms tend to exhibit highly concentrated ownership of voting rights. For the typical dual class firm, approximately 96 percent of all stockholders own shares of the inferior voting class. ${ }^{40}$

Fourth, dual class firms are characterized by a significant amount of family control. In many dual class firms, two or more related individuals (by blood or marriage) currently hold top management positions and family members have sometimes held such positions for several generations. ${ }^{46}$ Fifth, most dual class firms are conservatively leveraged. The average ratio of long-term debt to total assets for dual class firms is approximately $0.1 .^{47}$ Sixth, dual class firms frequently issue new equity within a short time after recapitalizations. ${ }^{48}$ Thus managers' desire to issue new equity without diluting their proportionate ownership of voting rights also appears to be a motivation for recapitalizations.

41 The most important studies are DeAngelo and DeAngelo, $14 \mathrm{~J}$. Fin. Econ. 33 (cited in note 32); Ronald C. Lease, John J. McConnell, and Wayne H. Mikkelson, The Market Value of Control in Publicly-Traded Corporations, 11 J. Fin. Econ. 439 (1983); and Partch, J. Fin. Econ. (cited in note 40).

12 See DeAngelo and DeAngelo, $14 \mathrm{~J}$. Fin. Econ. at 45 (cited in note 32).

43 It is also true, however, that managers own a large percentage of the outstanding votes (an average of 48.6 percent) prior to recapitalizations. See Partch, J. Fin. Econ. (cited in note 40) (table 3).

14 See DeAngelo and DeAngelo, 14 J. Fin. Econ. at 47 (cited in note 32).

ts Id. at 41.

16 Id. at 30 .

47 Id. at 41.

40 Approximately one-third of dual class firms issue new equity within one year after the creation of the limited class voting stock. Partch, J. Fin. Econ. (cited in note 40) (section 2.4). This figure should be compared with the results of another study that found that only 17 percent of a random sample of industrial firms actually completed sales of common stock publicly at least once within an eleven-year period. See Wayne H. Mikkelson and M. Megan Partch, Valuation Effects of Security Offerings and the Issuance Process, 15 J. Fin. Econ. 31,36 (1987) (table 2). 
These characteristics of dual class firms are consistent with the theory of insider control discussed above. Dual class common stock enables managers to control a majority of votes without owning 51 percent of the outstanding shares. The large family involvement in many dual class firms suggests one reason why insiders value control. Protecting firm-specific investments of human capital and economizing on the costs of communicating information to investors to avoid takeovers may, as discussed above, be other reasons. The highly concentrated ownership of votes in dual class firms further suggests that such arrangements may overcome collective action problems faced by dispersed shareholders.

The frequency with which newly recapitalized dual class firms issue new equity is also consistent with the analysis of the costs and benefits of control. Constraints based on wealth as well as lack of diversification may make managers reluctant to pursue investment projects if obtaining the necessary financing would dilute their voting rights. Thus, dual class common stock enables insiders, who in many cases already have control, to finance new projects without fear of loss of control.49

Finally, the theory of insider control predicts that the reduced effectiveness of the market for corporate control as a monitoring device would lead dual class firms to rely more heavily on alternative monitoring mechanisms. The evidence seems to support this view. In particular, the family ownership of many dual class firms may act as a substitute for the market for corporate control. The obligation that family members feel to each other may act as a constraint on self-interested behavior that reduces the value of the firm. Similarly, the significant equity interest of managers in dual class firms, even though less in percentage terms than their ownership of votes, tends to align the interests of managers and investors.

2. Pricing of dual class common stock. Researchers have studied the relative prices of multiple classes of equity securities with unequal voting rights. ${ }^{.0}$ The typical procedure is to consider

19 The frequency with which newly recapitalized dual class firms issue new equity also acts as a safeguard for investors. Because capital markets penalize inefficient arrangements, when owner/managers go to the capital market frequently, their incentive to adopt voting rules that are harmful to investors is reduced.

${ }^{\text {so }}$ See Lease, McConnell, and Mikkelson, 11 J. Fin. Econ. 439 (cited in note 41). Haim Levy, Economic Evaluation of Voting Power of Common Stock, 38 J. Fin. 79 (1982), provides evidence for the Israel Stack Exchange that is similar to that discussed in this article. DeAngelo and DeAngelo, $14 \mathrm{~J}$. Fin. Econ. 33 (cited in note 32), examined forty-five dual class firms, but focused mainly on other characteristics of these firms. 
firms for which (1) both classes of stock are publicly traded in the same markets; and (2) the two classes differ only with respect to voting rights-that is, each class has identical rights to any cash distributions. The purpose of this procedure is to isolate the value of the vote to the investors.

Lease, McConnell, and Mikkelson (LM\&M) studied the share prices of thirty companies that had two classes of publicly traded common stock outstanding during the period from 1940 to 1978-classes that had unequal voting rights but were otherwise identical. Twenty-six of these firms had two classes of common stock and no other voting securities. Four of the firms had voting preferred stock in addition to the two classes of common stock.

Month-end prices for the two classes of common stock from the same day of trading were used to calculate the value of voting rights. Specifically, LM\&M calculated for each firm the ratio of the superior voting stock's month-end price to the inferior voting stock's price at the end of the same month. They then took the average of these ratios. If investors valued superior and inferior voting shares equally, this average ratio should be one. If the superior voting shares were more highly valued, the average ratio should exceed one and if the superior voting shares were valued less, the average ratio should be less than one.

For the twenty-six firms that had two classes of common stock and no other class of voting securities, LM\&M found that the average observed ratio of month-end prices was greater than one. The average price premium placed on the shares with superior voting rights relative to the class with inferior voting rights was 5.4 percent. For the four firms with voting preferred in addition to two classes of common stock, however, they found that the average observed ratio of month-end prices was less than one. The average discount of the superior voting class of common stock was 1.25 percent. Both results are statistically significant..$^{\text {s1 }}$

The existence of these premiums and discounts may seem surprising. The price of a security, like any other asset, should reflect the present value of future cash flows. Since the sample was constructed to include only those securities with guaranteed identical rights to future cash flows, finance theory predicts that the prices of the different classes of common stock should be identical-regardless of voting rights.

A possible explanation for the premiums and discounts is that

s1 Lease, McConnell, and Mikkelson, 11 J. Fin. Econ. at 469 (cited in note 41). 
the holders of one class of securities rationally anticipate different net cash flows regardless of the charter provision guaranteeing identical payoffs. LM\&M examined various possibilities. They found that the corporate charters of the firms studied expressly forbid cash buy backs at premium prices and sales of new securities at discounts that would benefit one class and not the other. Nevertheless, the receipt of different benefits is still possible. For example, those with voting control may anticipate a premium price for their shares in the event of a takeover bid. Alternatively, those with control may be able to benefit by directing the firm's resources to their own gain. A firm, for example, may purchase inputs from (or sell outputs to) another firm owned by the controlling stockholders at above (or below) market prices.

Some direct evidence on these points is provided by DeAngelo and DeAngelo. ${ }^{52}$ They examined corporate takeover payments to both classes of stock for firms that had dual classes outstanding when acquired. Differential compensation was paid in one-third of the cases they studied. ${ }^{53}$ These instances of differential payoffs in the event of an acquisition may help explain why investors are willing to pay a premium for the superior voting class. The possibility of a higher payoff when acquisitions occur also may explain why shareholders who exchange voting shares for limited voting shares frequently receive rights to a slightly higher dividend. The higher dividend is compensation for the lower expected payoff in the event of an acquisition. ${ }^{54}$

3. The effect of dual class common stock on investors' wealth. Firms may issue limited or non-voting stock in two circumstances. They might offer such securities when they go public. Al-

${ }^{62}$ DeAngelo and DeAngelo, 14 J. Fin. Econ. 33 (cited in note 32).

ss They discovered thirty such events that occurred between 1960 and 1980 . Of these, they found no explicit direct or indirect payments in twelve cases. In six cases, they found that different compensation, which was difficult to value, was paid to different classes (an example is the sale of a division at book value to a manager). In eight cases, both classes received equal compensation per share as a result of the acquisition-even though the inferior class had been entitled to a slightly higher dividend payout. Finally, they identified four cases in which the superior class received explicit (and often substantial) premiums per share. See DeAngelo and DeAngelo, 14 J. Fin. Econ. at 57 (cited in note 32).

s4 LM\&M's finding that superior voting shares sell at a small discount when there is a class of voting preferred outstanding is more of a puzzle. The small sample size (only four firms) suggests that their finding may be an aberration. If it is not, one possible explanation is that the value of control in some situations may be negative. If the holders of control gained indirect benefits from control in the past, for example, they may face costly legal claims. If a more complicated ownership structure (such as a structure with two classes of common stock and a class of voting preferred) makes costly legal claims more likely, this may cause superior voting shares to sell at a discount. 
ternatively, firms that are already publicly owned may recapitalize by offering such securities to existing shareholders or the general public.

As a theoretical matter, initial public offerings of limited or non-voting stock can never harm investors. The price of a security when a firm goes public reflects the value of that security to investors. Investors only purchase a security when they estimate that the value of whatever rights and cash flows it carries equals or exceeds its price. If investors value voting rights and a firm fails to provide them, then the firm's securities simply sell at a lower price. The organizers of the firm may be worse off, but investors are not.

Recapitalizations pose a different issue. Such recapitalizations may increase investors' wealth if, for example, they protect firmspecific investments of human capital or they signal that the firm has valuable investment opportunities that will be financed by new equity issues. This possibility can be described as the shareholder interests explanation of recapitalizations. Alternatively, recapitalizations may reduce investors' wealth by insulating incumbent management from the discipline of the market for corporate control. This possibility can be described as the management entrenchment explanation of recapitalizations.

To distinguish between these two explanations for dual class common stock, Megan Partch studied forty-four recapitalizations that occurred from 1962 to 1984 in which a publicly traded firm issued a new class of limited voting stock..$^{\text {s5 }}$ She found that the average stock price reaction to the announcement of plans to create dual class common stock was positive, and that investors experienced larger positive wealth effects when insiders already owned a large percentage of votes prior to the recapitalization. Thus, the market responds more positively to proposals to issue limited voting stock when the motivation of the recapitalization is

ss Partch, J. Fin. Econ. (cited in note 40). Specifically, Partch examined the changes in wealth experienced by investors on and between certain "event" dates. The event dates were the date of the board of directors' meeting where the proposal was made, the date of the proxy mailing on which the proposal was made public, and the date of the shareholders' meeting on which the proposal was approved.

On the most important day, the day the recapitalization proposal was announced, investors experienced a positive and statistically significant return of 1.2 percent. Investors also experienced a positive and statistically significant return on other event dates. The overall return experienced by investors from the time of announcement to the time of approval was negative, but not statistically significant. The overall returns from announcement to approval was a less direct test of the wealth effects of creating limited voting stock than the returns on event days. The reason is that the interval between announcement and approval necessarily includes events unrelated to the creation of limited voting stock. 
to maintain rather than gain control. ${ }^{56}$ Thus shareholders seem to be voting rationally when they approve recapitalizations creating dual class common stock.

In another study, Gregg Jarrell has found that NYSE listed firms experienced abnormal losses following the announcement of proposals to create dual class common stock. ${ }^{57}$ The reason for such losses may be the risk of delisting if dual class common stock is adopted. This might explain the negative returns, except that it is a puzzle why firms risk delisting (and shareholders approve) if doing so is wealth-reducing. One possibility is the very fact that firms would risk delisting signals the market that the firm has particularly bad prospects. Another possibility is that the market for corporate control is more important as a monitoring device for NYSE firms because they tend to be larger and have lower insider holdings. The proposed recapitalization, under this view, is perceived by investors as a form of managerial entrenchment. Even if this view were correct, however, it would not explain why shareholders approve recapitalizations for NYSE firms.

With the exception of NYSE firms, the evidence suggests that recapitalizations creating dual classes of common stock are consistent with shareholders' interests. This result, however, should be interpreted with some caution because Partch's findings are preliminary and have not yet been replicated by other investigators. In addition, the potential exists for particular recapitalizations to harm stockholders. Nevertheless, the evidence does demonstrate that for an important class of firms, recapitalizations have been beneficial. Based on the current evidence, therefore, no basis exists for the conclusion that investors as a class would benefit from a blanket prohibition of the use of dual classes of common stock.

\section{Dual Class Common Stock and Defensive Tactics in Response to TakeOVERS}

Considerable evidence now exists that shareholders of target companies experience significant increases in wealth as a result of hostile takeovers. On average, a target's shareholders experience an increase in the value of their shares of approximately thirty per-

so Significantly, for the entire sample, Partch found that insiders controlled an average of 48.6 percent of the votes at the time of the recapitalization.

${ }_{87}$ Gregg A. Jarrell, The Stock Price Effects of NYSE Delisting for Violating Corporate Governance Rules (unpublished manuscript, Dec. 1984, on file with The University of Chicago Law Review). 
cent as a result of a successful takeover attempt. 58 These gains are, on average, lost in their entirety if the target's managers are able to defeat the offer by engaging in defensive tactics and the target is not acquired by another bidder. ${ }^{59}$ Moreover, several studies indicate that shareholders of target corporations typically experience a statistically significant decrease in the value of their shares when management engages in defensive tactics. ${ }^{60}$

Overall, the evidence indicates that shareholders of targets benefit from takeovers and are harmed by defensive tactics that make takeovers more difficult. Shareholders of bidding firms and shareholders as a class also are likely losers if defensive tactics cause fewer acquisitions to occur and make those that do occur more expensive. As a result, several commentators have argued that shareholders' wealth would be maximized if managers did not engage in defensive tactics to resist hostile takeovers. ${ }^{61}$

Concern has been expressed that dual class common stock may be another form of defensive tactic that operates to the detriment of investors. Without question, there is some basis for this concern, particularly with respect to the NYSE listed firms that have risked delisting. Nevertheless, to equate dual class common stock with defensive tactics taken in response to perceived takeover threats is misleading for several reasons. First, the claim is not factually accurate. Many firms have had dual classes of common stock for several generations-some from their inception as

ss Michael C. Jensen and Richard S. Ruback, The Market for Corporate Control: The Scientific Evidence, $11 \mathrm{~J}$. Fin. Econ. 5, 10 (1983) (summarizing the results of thirteen studies of takeovers).

s9 See Michael Bradley, Anand Desai, and E. Harv Kim, The Rationale Behind Interfirm Tender Offers: Information or Synergy?, 11 J. Fin. Econ. 183, 194 (1983).

- For example, Dann and DeAngelo studied acquisitions, divestitures, issuances of additional voting stock, and repurchases of voting stock by target firms in response to hostile takeover attempts. They found a statistically significant abnormal return of 2.33 percent on average when these changes were announced. Larry Y. Dann and Harry DeAngelo, Corporate Financial Policy and Corporate Control: A Study of Defensive Adjustments in Asset and Ownership Structure (Working Paper No. MERC 86-11, U. Rochester Grad. Sch. Mgmt., Aug. 1986). See also Paul H. Malatesta and Ralph A. Walking, Poison Pill Securities: Stockholder Wealth, Profitability, and Ownership Structure (Working Paper, U. Washington, Sept. 1986); Larry Y. Dann and Harry DeAngelo, Standstill Agreements, Privately Negotiated Stock Repurchases, and the Market for Corporate Control, 11 J. Fin. Econ. 275 (1983). Some contrary evidence also exists. See Gregg A. Jarrell, The Wealth Effects of Litigation by Targets: Do Interests Diverge in a Merge?, 28 J. L. \& Econ. 151 (1985). Jarrell finds that when litigation leads to additional bids from rival acquiring firms, target shareholders earn abnormal positive returns.

-1 See, e.g., Alan Schwartz, Search Theory and the Tender Offer Auction, 2 J. L. Econ. \& Org. 229 (1986); Frank H. Easterbrook and Daniel R. Fischel, The Proper Role of a Target's Management in Responding to a Tender Offer, 94 Harv. L. Rev. 1161 (1981). 
publicly held firms. DeAngelo and DeAngelo found that the median firm in their sample had a dual class voting structure for about twenty years. ${ }^{62}$ Similarly, Partch found that no firms in her sample were the subject of a takeover attempt in the two years prior to the recapitalization. ${ }^{63}$ Furthermore, many recapitalizations are better understood as attempts to maintain control of a firm in light of anticipated additional equity financing rather than attempts to prevent outsiders from taking over the firm. Transfers of control in such cases are not at issue; the issue is whether the firm, given that there will not be a transfer of control, will be able to finance new projects with equity. Moreover, as the example of General Motors demonstrates, shares with limited voting rights are sometimes issued for reasons having nothing to do with the prevention of transfers of control.

Second, not all transactions that make hostile takeovers more difficult are necessarily harmful to investors. No one could credibly argue, for example, that the failure to take a firm public is necessarily harmful to investors. Similarly, the evidence suggests that going private is beneficial to investors. ${ }^{64}$ The relevant issue is the importance of the market for corporate control as a monitoring mechanism in comparison with other monitoring mechanisms for any particular firm.

A third reason why dual class common stock should not necessarily be equated with defensive tactics to fend off takeovers is that many dual class firms are eventually acquired.65 The dual class structure may allow management to negotiate more effectively on behalf of investors. ${ }^{68}$

Finally, dual class common stock varies from other defensive tactics adopted in response to takeover threats both in terms of the procedural safeguards involved and in their effect on investors' wealth. Most defensive tactics in response to takeovers tend to be changes that managers can implement quickly and without the approval of shareholders. These types of defensive tactics tend to have a negative effect on shareholders' wealth. Recapitalizations creating dual classes of common stock, by contrast, typically must

${ }^{62}$ DeAngelo and DeAngelo, $14 \mathrm{~J}$. Fin. Econ. at 53 (cited in note 32).

${ }^{63}$ Partch, J. Fin. Econ. (cited in note 40) (section 2.4).

64 Harry DeAngelo, Linda DeAngelo, and Edward M. Rice, Going Private: Minority Freezeouts and Stockholder Wealth, 27 J. L. \& Econ. 367 (1984).

${ }^{8 s}$ DeAngelo and DeAngelo, $14 \mathrm{~J}$. Fin. Econ. at 57 (cited in note 32).

${ }^{66}$ It is not clear, however, that actions by a target's management that maximize the price paid per offer necessarily maximize the welfare of shareholders as a class. See note 36 and accompanying text above. 
be approved by shareholders. And most importantly (with the exception of NYSE listed firms), there is no evidence that the implementation of dual classes of common stock reduces investors' wealth. ${ }^{67}$

\section{A Note on the NYSE and the One Share, One Vote Rule}

The NYSE is now attempting to change its historic policy against listing dual class common stock. The stated reason for this possible change is competitive pressure from the other exchanges. The above discussion suggests that the competitive effects of a change in rules by the NYSE are more complex than might first appear. To be sure, a change in rules might allow the NYSE to keep listings of firms that want to adopt dual class common stock. The preliminary evidence indicates, however, that recapitalizations for NYSE firms adopting dual class common stock have caused large negative wealth effects. Assuming that these effects are not caused by the threat of delisting, if NYSE rules are changed to permit these large negative wealth effects to occur, listing on the NYSE will be less valuable to investors. All else being equal, the NYSE will lose listings as a result or be forced to charge less for the transactional and ancillary services it provides. Thus, the NYSE appears to face a clear tradeoff in deciding whether to change its rule.

Put differently, the NYSE's historic rule can be seen as a means whereby management could make a commitment to stockholders of certain types of firms that takeovers would not be resisted by creating dual classes of common stock. Tough delisting standards made this commitment all the more credible. Under this interpretation, the change in the NYSE rule will allow managers of certain firms to break this commitment. Thus, the proposed change may have certain short-term gains for the NYSE but may also impose long-term losses, because a bonding mechanism aligning the interests of managers and investors will no longer be available.

There is, however, another, equally plausible interpretation of

67 In this sense, there is a similarity between dual class common stock and antitakeover amendments that also must be approved by shareholders and generally do not have significant effects on wealth. Regarding the evidence on the effects of antitakeover amendments on shareholders' wealth, see Scott C. Linn and John J. McConnell, An Empirical Investigation of the Impact of "Antitakeover" Amendments on Common Stock Prices, $11 \mathrm{~J}$. Fin. Econ. 361 (1983); Harry DeAngelo and Edward M. Rice, Antitakeover Charter Amendments and Stockholder Wealth, 11 J. Fin. Econ. 329 (1983). 
the effect of the NYSE's proposed change in voting rules. Under this alternative interpretation, the change will increase the flexibility of firms listed on the NYSE. In theory, this increase in flexibility may be beneficial for at least certain firms. The proposed rule change, in other words, might allow NYSE listed firms to obtain the benefits of dual class common stock to the same extent as nonNYSE listed firms.

The existing empirical evidence does not generate unambiguous predictions of what the consequences will be if the NYSE changes its rule. While recapitalizations of firms listed on the NYSE appear to have caused large negative wealth effects, the evidence is meager. And, as discussed above, the negative wealth effects may have been caused by the threat of delisting rather than any problem inherent in dual class stock. The evidence to date is not sufficient to generate a meaningful prediction of what the wealth effects will be of recapitalizations for NYSE firms if these firms do not risk delisting.

Similarly, it is not obvious that a change in the NYSE rule will prevent managers from making credible commitments to shareholders of certain firms not to resist takeovers by creating dual classes of common stock. The same commitment can be made by contract, perhaps in the corporate charter with special provisions defining the rules for amendment. In short, it is simply not possible at this stage to predict what the ultimate effect will be of a change in the NYSE's prohibition on the listing of dual class common stock.

\section{Conclusion}

Dual class common stock appears to be beneficial for investors of a small minority of firms. Accordingly, the willingness of certain organized exchanges to list the dual classes of common stock of these firms similarly has been beneficial. It does not follow, however, that all exchanges should have the same governance rules. It is impossible to predict whether the proposed change of the NYSE's historic prohibition on the listing of dual class common stock will, if implemented, harm or benefit investors. 